\title{
Historicizing Karl Polanyi
}

\section{Marcus Gräser}

(C) The Author(s) 2019

\begin{abstract}
Karl Polanyi's book The Great Transformation has found great resonance in the social sciences in recent years-especially in sociology, political economy and political science. The interest in Polanyi among historians is still modest in comparison. There are not enough studies that treat Polanyi as an object of intellectual history/history of science, nor has Polanyi been used hitherto as an idea-giver for the growing field of global history-despite the fact that his book can be understood as global history. It is high time to "historicize" Polanyi in several ways.
\end{abstract}

Keywords Karl Polanyi · Great Transformation · Global History · History Writing

\section{Karl Polanyi historisieren}

Zusammenfassung Karl Polanyis Buch The Great Transformation hat in den letzten Jahren in den Sozialwissenschaften viel Aufmerksamkeit gefunden - vor allem in der Soziologie, der Politischen Ökonomie und der Politikwissenschaft. Im Vergleich dazu ist das Interesse an Polanyi in der Geschichtswissenschaft zurückhaltend. Weder gibt es ausreichend Studien, die Polanyi in die Ideen- und Wissen(schaft)sgeschichte seiner Zeit einbetten, noch hat er bislang eine Rolle in den Debatten über Globalgeschichte gespielt. Höchste Zeit also, Karl Polanyi auf verschiedene Weise zu „historisieren“.

Schlüsselwörter Karl Polanyi · Great Transformation · Globalgeschichte · Geschichtswissenschaft

M. Gräser $(\bowtie)$

Institut für Neuere Geschichte und Zeitgeschichte, Universität Linz, Altenbergerstraße 69, 4040 Linz, Austria

E-Mail: marcus.graeser@jku.at 
Karl Polanyi has finally become popular. Although the American sociologist Johanna Bockman's comment that Polanyi is, next to Michel Foucault, "probably the most popular theorist among social scientists today" seems somewhat exaggerated (Bockman et al. 2016, p. 386), there is no question that Polanyi's critical picture of market fundamentalism and its disastrous consequences for democracy, which he sketched out in his 1944 book The Great Transformation (Polanyi 1944, hereafter cited as GT), has met with ever-growing interest among social scientists since the financial crisis of 2007/2008. There is no risk of error in postulating that "the already widespread use of Polanyi's work in social sciences promises to continue to expand" (Bockman et al. 2016, p. 386). Historians, interestingly, have hardly participated in this Polanyi renaissance so far: not much work has been done on Polanyi from the point of view of intellectual history and/or the history of science, and neither has the growing interest in global history, which for some years now has dominated the international discussion on historiography, led to an interest in Polanyi-astonishingly, since Polanyi's GT offers if not a global history of the market society then at least a globally informed interpretation of economic history and its political implications since the early 19th century. Also, his book contains keywords and theoretical models that could be fruitful for global historical research.

There are of course exceptions to this observation of historians' disinterest: Daniel Immerwahr, in an essay published in 2009 in the Journal of the History of Ideas, presented a first attempt at putting Polanyi in the historical context of the discussion on economics and society at mid-century, and Howard Brick has assigned a special place to Polanyi in his book on American theories of social liberalism and visions of developments leading beyond capitalism (Immerwahr 2009; Brick 2006). Tim Rogan, in a recently published book, gave Polanyi a very prominent role in the context of English debates on moral economy (Rogan 2017). The indispensable triad of books on Polanyi written by Gareth Dale (Dale 2010, 2016a, 2016b) as well as the work done by the sociologists Fred Block and Margaret R. Somers (Block and Somers 1984, 2014) serve as a stable basis for anyone who wants to study Polanyi within the context of his times. But there is still something of a mismatch between the growing popularity of Polanyi and historical knowledge about him, his work and how it all corresponded to the intellectual and scientific situation of the 1930s and 1940s. This desirable historical knowledge is indispensable for a good use of Polanyi's thinking today: no actualization without historicization.

What does 'historicization' mean in this context and what function can it fulfil in the recent Polanyi discussion? Above all, historicizing Polanyi does not mean regarding him as ancient; neither does it mean declaring him a monument. The fact that Polanyi's work is attuned to contemporary concerns makes it urgent that we learn not only how he sought specific historical answers to the questions he posed, but also how his work originated and resonated in the intellectual arena at the time the book was written. In that sense historicization means two things: firstly, the clarification of the specific historical context in which Polanyi had conceived and written his book (1), and secondly an interpretation of his work as a genuine contribution to the field of historiography, and hence an attempt to place it in the context of Anglo- 
American historical sciences in the $1940 \mathrm{~s}^{1}$ (2). Against this background, some of the difficulties in the reception of the work, not solely among historians, can at least be clearly marked and described, if not fully explained (3).

\section{1.}

The reference to the fact that Polanyi's GT is transversal to disciplinary boundaries is often used as an explanation for the rather difficult and not altogether satisfying reception of the book in the immediate aftermath of its publication: GT was supposed to be too sociological to be recognized by historians and contained too much history to be of interest to economists etc. In fact, Polanyi did not conceive of GT as an academic monograph written for colleagues and for the purpose of enhancing his own career within a certain academic field. Polanyi wrote GT primarily as a diagnosis of his times, certainly on a scientific basis, but-for the sake of political clout - aimed at a broad public audience. His book was meant as a contribution to the intellectual debate on the crises of capitalism and liberal democracy in the 1940s, the opportunities for a revitalization of democracy in the face of fascism and the design of the post-war order. It is no coincidence that the first British edition of the book was published in 1945 under the title "Origins of Our Time" (Polanyi 1945) — a title that had been favoured by Polanyi. And it is not by chance that there is a temporal connection between Polanyi's analysis and the New Deal, the great transformation of American politics after Franklin D. Roosevelt became president in 1933, witnessed by Polanyi in his American years (starting from 1940). Ira Katznelson, in his book Fear Itself: The New Deal and the Origins of Our Time, cites Polanyi's point of view that what was at issue in the 1930s as well as in the following decade was not just freedom, but "the meaning of freedom itself." The answer to these issues, says Katznelson, was given by the US and the politics of the New Deal (Katznelson 2013, p. 476). The welfare policy of the New Deal and the rise of state interventionism was part of the complex of what Polanyi called 'countermovement', a term that was meant to capture the emergence of social movements as well as patterns of statehood that counteracted the rule of the market society.

For the contemporaries of Polanyi, GT was a book written in support of New Deal policy: Stuart Chase's 1945 book Democracy under Pressure: Special Interests vs. the Public Welfare, was among the first books ever to include an appraisal of GT. After an approving presentation of Polanyi's main theses, Chase wrote: "If the market is destructive to that vague but powerful entity which we call society, then it followed naturally that we should have government interference, labor unions, and business monopolies-Big Business, Big Labor, Big Government" (Chase 1945, pp. 62-67). Polanyi himself expressed approbation for the New Deal. In a letter of 1943 to his political mentor from the days in Hungary, Oscar Jaszi, Polanyi wrote: "I don't believe in a totally planned economy. [...] I believe in a New Deal which

\footnotetext{
1 The interpretation of Polanyi's book as a historiographical work is one possible way of classifying GT-but it is certainly not meant as an exclusive reading, insofar as Polanyi was a genuinely interdisciplinary-minded scholar.
} 
relies on a clear conception instead of opportunistic, unresolved, confused, and unprincipled intervention in everything" (Polanyi, Letter to Oscar Jaszi, March 1, 1943, as cited in Litvan 1991, p. 259f.). This quote expresses a scepticism towards the state that Polanyi carried around-he preferred the self-organization of society over the "state" (Bockman et al. 2016, p. 395; Block und Somers 1984, p. 68). Nevertheless, institutions of the New Deal met with his approval: "The TVA [the Tennessee Valley Authority was, and still is, a federally owned corporation providing for the economic and energetic development of the Tennessee Valley; MG] and the excellent conserving administration of the New Deal show that land can't be surrendered to the market" (Polanyi, Letter to Oscar Jaszi, March 1, 1943, as cited in Litvan, p. 260). He had long since developed a positive view of America-beyond the New Deal. American democracy seemed to be relatively close to that self-organization of society which was, in his eyes, a very effective counterpart to market dominance. In a lecture on "Jean Jacques Rousseau, or is a free society possible," which he gave in April 1943 at Bennington College, Polanyi said: "For what American Democracy means to the world at large is nothing else but a way of life in which the people themselves, and not their betters or superiors, are the actors" (Polanyi 1943a, p. 11. For Polanyi's view on America, see also Dale 2016a, p. 144-147).

Although the experience of the New Deal (and the strengthening of state intervention through the needs of wartime economy) represented, for Polanyi, the historical momentum from which his market-critical argument could plausibly be made, his interest in a diagnosis of his times originated in the early 1920s, when he started searching for the "origin of this agony and pain", as he wrote in 1920 in an unpublished manuscript titled Behemoth (cited after Polanyi-Levitt and Mendell 1987, p. 22). This early trace of the days in Vienna also makes it clear that for Polanyi, as for many intellectuals of his generation, the First World War represented shock and caesura. $^{2}$

The view that GT is a historically informed diagnosis of the times also allows for a comparison with at least four other great diagnoses written by European intellectuals in exile in the United States: Hannah Arendt's Elements and Origins of Total Rule, Emil Lederer's State of the Masses, Eduard Heimann's Freedom and Order, and Theodor W. Adorno's and Max Horkheimer's Dialectic of the Enlightenment (Arendt 1951; Lederer 1940; Heimann 1947; Adorno and Horkheimer 1947). As different as these books, including Polanyi's, may be, they all work with a historical perspective, are oriented towards social science methodology, are looking for a new understanding of the relationship between politics and economics, and share the sense of a secular breach, a rupture in civilization (Zivilisationsbruch) that had emerged with the rise of German fascism since the 1930s. But in all these cases, the roots of cataclysm were not located in the immediate history of fascism, but explained in the long run from the 19th century. The acumen of all these analysts

\footnotetext{
2 The significance of "Red Vienna" and the economic policy debates of the 1920s in which he participated should not be underestimated in the analysis of Polanyi's work. Nevertheless, the idea of a linear biographical development, in which all experiences of life are always equally present and incorporated into the work, is not suitable as an analytical instrument. In Polanyi's case, the question that must be asked is whether his emigration to England represents a strong biographical break and whether the essential impulses for GT did not emerge until the 1930s.
} 
sets a good example of the dictum that Reinhart Koselleck has formulated: "History may be made - in the short term-by winners, but historical knowledge comes-in the long run-from the vanquished" (Koselleck 2000, p. 68).

In writing an intellectual history of Polanyi and his work in the context of the American intellectual and scientific landscape in the 1940s, it may be useful to choose an interpretative model that insists on the entanglement of experience and method. Koselleck has written an influential essay on change of experience and change of method (Erfahrungswandel und Methodenwechsel) and noted that what is sought, found and presented as historical truth never depends solely on the experiences undergone by the author. But neither does it depend solely on the methods he uses. Polanyi's 'change of method' was first of all a way of getting rid of 'national' economics, and analyses what is now called 'first globalization' in historical research. This was accompanied by a rather eclectic application of methods that came from economics, sociology, anthropology, and historical science.

Wherever, as in the case of the GT, an actual rewriting of history takes place, the change of experience and the change of method are inextricably linked. For this reason, the rewriting of history necessarily carries an element of diagnosis of the times. Koselleck points out in his model that, of course, there is a time gap between the change of experience and the change of method, insofar as the shock of the new experience must already have been worked up. The diagnosis of the times does not result from a surprise, but from taking stock of what seemed to be new.

The conciseness of Polanyi's diagnosis of his times is due to the entanglement of analysis of the present and the historical argument. The one could not exist without the other. The analysis of the present without a search for the "origin" would not be valid-and the historical argument would be worthless-especially for a nonhistorian like Polanyi, if it does not make a diagnostic sense for the purpose of a politically enlightened discussion. As late as 1943, Polanyi planned the separate publication of the parts of the story-the historical analysis and the diagnosis of his times. He wrote in a letter to his brother Michael: "I have been asked to write a short book for my American publishers [...] which [should] attempt to apply the results of the bigger book to all-round policy. I gladly accepted, since it helps to keep the book free from politics" (Polanyi, letter to Michael Polanyi, July, 8 1943b). The 19th century was originally intended to provide the framework for the entire book: in 1941 Polanyi had thought in a letter to his brother about the title of his work. "I will probably call it "Anatomy of the 19th century. Political and Economic Origins of the Cataclysm"' (Polanyi, letter to Michael Polanyi, August, 22 1941). But a splitting of the content fortunately did not happen and the "bigger book" benefited from that decision: the chapters of the third part, focussing on Polanyi's own time, do not come along as foreign matter; they rather seem like an extension of the argument into the present, after the first two parts had strongly recurred to the 19th century. 


\section{2.}

The clarification of the "origins" in the 19th century was, for Polanyi, more than merely an 'introduction' to the present and was supposed to have its own value. His study of the sources and the relevant historical literature, especially English economic and social history, and the historiographical minimum of chronology and causality, which he carefully observed, did not earn him the respect of historians. Above all, his remarks on the Speenhamland system, which play an eminent role in his argument, were not accepted by his contemporaries-and the assessments have not changed since (Rogan 2017, p. 80; Eisenberg 2011; Steinberg 2016). Nevertheless, the historians' early criticisms were rooted in a traditional ideology of how to approach an understanding of the past: the British historian Arthur Redford, for example, measured the interpretation, that Polanyi presented, at the consciousness of the contemporaries of the 19th century: "Has your brother," he asked his acquaintance Michael Polanyi, "evidence that people had in mind these considerations?" (Cited after Rogan 2017, p. 81). Indeed, focussing on the mind-set of nineteenthcentury actors was not Polanyi's intention. He argued anti-historistically and consulted his source material (which he had mostly found in the secondary literature) only as to which modern interpretation was permissible. However, the historists' criticism did not touch on the core of Polanyi's historical argument. While for the economic historian R.H. Tawney, who exerted a great influence on Polanyi with his major work Religion and the Rise of Capitalism, published in 1926, the defence of the human personality against the powers of commerce rested on the basis of the Christian faith, Polanyi did not want to use God, even implicitly: "Polanyi's defense of human personality rested not on belief in God but faith in history" (Rogan 2017, p. 79. For Tawney's influence on Polanyi, see also Dale 2016a, p. 127-134).

In fact, Polanyi was convinced that GT belonged "in the realm of universal history" (Polanyi, letter to Michael Polanyi, August, 22 1941). He in fact had little to do with academic history, not in England and even less in the United States. Polanyi took up an outsider position, not only in economics, but also in the field of history. This does not mean that Polanyi did not want to contribute to the further development of historical science. There is some evidence that allows for a characterization of GT as global history avant la lettre, which, for the sake of its argument, cannot do otherwise than abandon the nation-state framework that had been customary for the conventional historiography of the 1930s. "Polanyi was among the first," Fred Block and Margaret R. Somers were arguing, "to recognize the international context" (Block and Somers 1984, p. 65). Among those who, like Polanyi, did cast a glance at the international situation, the German historian Hans Rosenberg, who had to leave his country in 1933 and taught in the United States from 1936 on, came quite close to Polanyi's argument. Already in 1934 Rosenberg had published a small study on the World Economic Crisis of 1857-1859, and in 1943 his essay Political and Social Consequences of the Great Depression of 1873-1896 in Central Europe came out in the prestigious Economic History Review (Rosenberg 1934, 1943³). In

\footnotetext{
3 These works were later to be followed by a large overall presentation of the consequences of the economic depression in the late 19th century (Rosenberg 1967).
} 
contrast to Polanyi, Rosenberg was scientifically more precise and unassailable in his argument-he was, after all, a trained historian. His main interest was to grasp what Polanyi had in mind as 'cataclysm' — and in Rosenberg's case that implied the reasons for the economic depression as well as its consequences in the transformation of mass politics and political ideologies. But Rosenberg limited his research to central Europe. It would certainly not have occurred to him to use the term "universal history" to mark his position.

Does this term apply to Polanyi's work at all? The 1940s was, as Warren French has said, "one of the longest, unloveliest, and most ominously significant decades in human history" (Hutchinson 2018, p. 1). In the 1940s everything seemed to be possible: from human extinction to some real promise of universal peace and world government. A strong universalizing discourse became prevalent in these years: the first universal declaration of human rights, the first international war-crimes trials, and the creation of the United Nations are prime examples. This universalizing discourse that popped up in the 1940s in reaction to the destructive forces of fascism was desperately in need of economic, historical and philosophical explanations of what had happened and why it had happened. Polanyi's GT became a part of this universalizing discourse - and in this respect his claim of "universal history" was not misplaced.

His book was written as part of a universalizing discourse, at a time when a first run up at global historiography was emerging in the US. The Second World War and its truly global dimensions as well as the need for a grand strategy of American world politics sparked a movement in virtually all social sciences and humanities that broke away from the traditional fixation on national history (and the ever-privileged European history). Now "the world", the "one world", as it was called in a popular book by Wendell Willkie (Willkie 1943) and its history seemed to offer orientation or even guidance; or, to put in another way, the world was the given area for American politics and knowledge on the history of major trends, and world wide-development seemed to be a prerequisite for American hegemony. In 1941 Henry Luce, the prominent publisher of Life Magazine, had called for an "American Century" founded on American internationalism. Americans must "accept wholeheartedly our duty and our opportunity [...] to exert upon the world the full impact of our influence, for such purposes as we see fit" (Brinkley 2010, pp. 267-273). Luce's call for an American century found resonance not only among politicians and entrepreneurs but also among scientists and intellectuals. Luce's demand was not a loose promise or a hollow formula: America's dominance at mid-century rested, of course, on economic power and an unchallenged military might, it rested on a transatlantic consensus about anticommunism and containment-but the dominance of the US in the late 1940s also meant Keynesianism and welfare statism. For a while it looked like as if the New Deal could became a global affair insofar as a certain dose of state interventionism - as a countermovement - seemed to be an indispensable part not only of good government but also of modern statehood. The American model-a model of modernization-was ideological as much as institutional. It rested on a politics of productivity that was promoted by mass production, the use of technology, an open international economic order and organizational rationalization. 
Polanyi's attempt to grasp the causes and consequences of the Great Transformation transnationally fit into this tendency. Any attempt to universalize in historiography and to do global history could only come along as comparative history focusing "on the different means by which different societies manage similar problems" (Block and Somers 1984, p. 71) - and this is a fair description of what Polanyi is doing in his book. But the window to a global history soon closed: the division of the world into spheres of influence of the new superpowers, the beginning of the Cold War and the seizure of power by the communists in China at the end of the 1940s destroyed the vision of the one world that seemed to be necessary for global history. Universalist aspirations-in discourse as well as in politics- "were splintered by the Cold War and its residues, not by World War II" (Hutchinson 2018, p. 5).

What remained was a halved understanding of global history in the sense of an interpretation of the 'West' as a master example of modernization which-in a whiggish way-was understood as progress and showed the non-western parts of the world a mirror-image of good governance and development. In that Polanyi was not interested. His turn to the field of anthropology in the 1950s can be described as a departure from an internationalist interpretation of the development of the West, which, in Polanyi's case, did not pay tribute to a simple idea of progress but wanted to interpret the catastrophe.

\section{3.}

The attempt to evaluate Polanyi's GT as an approach for global history has not been a perspective of Polanyi's contemporaries. And in the numerous debates that are being held around global history today, the name Polanyi rarely appears. There are reasons for this: although GT has a global attitude, the construction is eurocentric and it resembles a typical 'master narrative' - a rather sceptical if not negative interpretation of Western Civilization. A critical interpretation of the 'West' is of course essential for today's global historiography-but the chosen form of a master narrative in a top-down fashion, monothematic and a bit manic, is nowadays not well-liked. The essential ingredients of modern global history-such as the linking of different regions of the world, the analysis of transfer and interaction, etc.- are lacking. To this day, reference is made to him only in the rather metaphorical manner of citing the familiar key concepts (embedding-disembedding etc.; see for example Mann 2012, pp. 64, 215, 236, 239, 242, 458). Polanyi's anthropological work is not used at all in contemporary global history writing. For this reason, it is difficult to predict whether Polanyi will play a role in the debate on global history or, to be more precise, in global historiography in the future. But it is not difficult to predict that Polanyi will still have a hard time among historians. Robert Kuttner's recent assessment that "in sum, Polanyi got some details wrong, but he got the big picture right" (Kuttner 2017, p. 57) is challenging for historians, since they usually see the big picture as depending on the coherence and accuracy of the details. 
But Polanyi's difficult reception history is not restricted to historians-and it is an old and sad story. If it is possible to overemphasise the extent of Polanyi's neglect, it is not possible to ignore it. For some, Karl Polanyi was in the shadow of his brother Michael, who always had enjoyed great prominence as a science theorist and chemist: "Among American scientists Karl was known as Polanyi's 'brother'. The 'real Polanyi' was Michael', Laura Fermi wrote in one of the first studies on the history of intellectual emigration from Europe in the decade before the outbreak of World War II (Fermi $1971^{2}$, p. 113). Almost harder still was the judgement of the sociologist Lewis Coser, who called Polanyi a "stranger [...] who stood largely outside the gate" (Coser 1984, p. 171). Coser was fair enough to give way to a different opinion: "Professor Hans Zeisel, in a personal communication (June 4, 1980) disagrees with this characterization and disputes my interpretation of Polanyi's marginality" (Coser 1984, p. 333). Zeisel, an emigrated Austrian social scientist, taught at American universities from 1943, ultimately (1953-1992) at the University of Chicago, and was a friend of Polanyi.

Was Zeisel right with his contradiction? What were the requirements for the attention that GT encountered immediately after its release, especially in the USA? Indeed, Polanyi was by no means an established scholar or well-known publicist at the time of publication. He had spent the 1930s in England, mostly outside the universities; he had given some lectures at American universities but was not known to a wider scientific audience. Bennington College in Vermont, where Polanyi lived from 1940, working on his book on the basis of a grant from the Rockefeller Foundation, was not a 'happening' place academically, at least not in economics or in political science. Bennington College was a women's college, very progressive, focusing on the arts, and became kind of popular in the 1930s through its Dance Summer Program with Martha Graham as the artistic teacher (Dale 2016a, pp. 157-160). Did Polanyi gain some prominence when his book came out and some of the leading magazines and newspapers published reviews in 1944 and the following years? ${ }^{4}$ An answer is difficult.

None other than John Dewey spoke of a "wonder" and declared that Polanyi had given "the best interpretation of general trends in 19th century history and 20th century up to date that I have ever seen" (Westbrook 1991, p. 460). For Dewey, GT was one of the major contributions to the debates surrounding the role of social sciences in democracy and the post-war world. President Roosevelt's State of the Union Address of January 11, 1944 had announced an initiative for a "second bill of rights", for "economic rights" in addition to the traditional political rights of the American constitution. What Roosevelt had in mind was the idea that human beings have inherent economic rights and that every modern government-especially an American government which actually was fighting through a bloody conflict with fascist and authoritarian regimes - has to establish policies of 'decommodification'. For this idea of modern statehood, GT of course provided accurately fitting arguments. Polanyi was by no means an outsider with his endorsement of planning in the second half of the 1940s - the war economy of nearly all major industrialized countries had shown the efficiency of (partially) managed economies, of organized capitalism, and

\footnotetext{
4 There is an impressive list of reviews in Polanyi (1986, p. 129).
} 
not only politicians but also intellectuals like Karl Mannheim, with whom Polanyi was familiar, had delivered strong pleadings for planning. Friedrich Hayek's book The Road to Serfdom, which had been published in the same year as Polanyi's GT, was a rather defensive warning against a state-dominated economy (Hayek 1944). By no means was this book the manifesto of a triumphant neoliberalism.

Polanyi must have seen his opponents not among the (then) small cohort of neoliberals, but rather among the technocrats whose relationship to democracy was rather dazzling. James Burnham, a former Trotzkyist who had turned into an ardent admirer of capitalism, had published his book on "The Managerial Revolution" in 1941 (Burnham 1941). In this book Burnham celebrates the rule of the specialized managers, who have replaced the old entrepreneur and are committed to a diffuse common good. In Burnham's view, the manager rules without control in a perfect regime of technocracy. Especially during the war, Burnham's vision seemed to be much more on point for the time than Hayek and the likes, whose vision of an economy free of any kind of state intervention always carried an old-fashioned air. Polanyi attacked Burnham in his article on "Our Obsolete Market Mentality", published 1947, as a protagonist of a "Brave New World", "where the individual is conditioned to support an order that has been designed for him by such as are wiser than he" (Polanyi 1947, p. 117).

Anyhow, Polanyi's book did not become a bestseller. GT sold just 1700 copies in 1944 and 1945 and the time window for any discussion of Polanyi's book was only brief (Kuttner 2017, p. 56). From the end of the 1940s, the public discussion on GT died out. Heimann was correct when he stated, in his book on "Freedom and Order" which came out in 1947 and touched upon the same bundle of problems that had engaged Polanyi, that GT had already become a "regrettably neglected work" (Heimann 1947, p. 7.) GT did not become a generational book, a book that college students carried around as textbook. Why was that so? When Polanyi burst onto the American scene with intellectual force, he was greeted, as Ira Katznelson put it in his wonderful book on Polanyi and Hannah Arendt, "with icy reserve within the mainstream disciplines, and, over the years was often dismissed as unsystematic, inconsistent, and empirically flawed" (Katznelson 2003, p. 51). There are attitudes and omissions in Polanyi's book that might have puzzled the American audience. There is a certain melancholy, a pessimistic attitude in presenting a story of capitalism and market society culminating in the world crisis of the 1930s and 1940s. Polanyi's book is economy noir. Disillusionment became a source for the arts in 1940s America, but science was supposed to be on the side of optimism.

Some Americans may have suspected a hidden philosophical agenda in Polanyi's book; his model-building approach smacked of a philosophy of history, transferred to the field of economics: "the great transformation was seen to be a one-way process" (Blyth 2002, p. 4). That was not completely mistaken: it seems that the idea of commodification is close to the concept of Verdinglichung (reification, objectification), a concept that had been shaped by Hegel, Feuerbach and Marx and was revived by Polanyi's fellow Hungarian Georg Lukács whose book on History and Class Consciousness was widely read and became one of the most influential reformulations of Marxist theory in the 1920s. Polanyi's way of juxtaposing movement and countermovement may qualify as a way of dialectical thinking that is close to 
Lukács's (Lukács 1971; Block and Somers 1984, p. 62; Block and Somers 2014, p. $73 \mathrm{f}$.). But Polanyi's interpretation carries a certain amount of non-dialectical thinking insofar as he underestimated the possibility of a synthesis of movement and countermovement, a synthesis that could and indeed did lead to the stabilization of capitalism. The theories of Keynes and the phenomenon of consumer society played a minor role in Polanyi's thinking.

Other omissions are also noteworthy and may have contributed to the difficult reception of the book especially in the US: Polanyi did not mention the Holocaust, he did not include imperialism and racism into his broad picture of a catastrophic development of western societies since the early 19th century and, astonishingly, he never thought about the war as an engine of transformation. ${ }^{5}$ These omissions are even more interesting — and need to be explained - because Polanyi constructed his analytical history of capitalist development by focusing less on the causal importance of this or that specific factor as contrasted with others than in how variables are connected in very specific instances.

Polanyi's GT came too early in some respects - and in other respects too late: for the criticism and delegitimization of the market and liberal capitalism his book came too late - the Great Depression of the years after 1929 was delegitimizing in itself and there was no shortage of critical literature in its wake. Also, Polanyi's interpretation of social policy as a countermovement had a prominent precursor in Heimann's book on Social Theory of Capitalism: A Theory of Social Policy which came out in 1929 and had introduced social policy as a "counter-principle" to capitalism (Heimann 1929). ${ }^{6}$ For a critical global history of the market, Polanyi came too early-neither among historians nor among economists did he find resonance space, which would have earned him professional recognition and a central position in a longer-lasting discourse. This paradoxical situation is an excellent starting point for a study of Polanyi in the context of Anglo-American intellectual history/history of science. An answer to the question of whether Polanyi's GT can exert a formative influence on the field of global history must be left open.

Funding Open access funding provided by Johannes Kepler University Linz.

Open Access This article is distributed under the terms of the Creative Commons Attribution 4.0 International License (http://creativecommons.org/licenses/by/4.0/), which permits unrestricted use, distribution, and reproduction in any medium, provided you give appropriate credit to the original author(s) and the source, provide a link to the Creative Commons license, and indicate if changes were made.

\section{References}

Adorno, Theodor W., and Max Horkheimer. 1947. Dialektik der Aufklärung. Amsterdam: Querido. Arendt, Hannah. 1951. The origins of totalitarianism. New York: Schocken.

\footnotetext{
5 Dale argues that Polanyi, who had relatives who lost their lives in the Holocaust, must have been aware of what was going on in the German occupied areas in Eastern Europe at least since 1942 (Dale 2016a, p. 177).

6 There are, of course, differences: Kari Polanyi-Levitt is right in mentioning the fact that Polanyi's countermovement is "not a self-correcting mechanism which moderates excesses of market fundamentalism but a contradiction in the Marxian sense of the word" (Polanyi-Levitt 2007, p. XIV). In comparison, Heimann's idea of social policy as a "counter principle" is indeed meant as a description of a correcting mechanism.
} 
Block, Fred, and Margaret R. Somers. 1984. Beyond the Economistic fallacy: The holistic social science of Karl Polanyi. In Vision and method in historical sociology, ed. Theda Skocpol, 47-83. Cambridge: Cambridge University Press.

Block, Fred, and Margaret R. Somers. 2014. The power of market fundamentalism: Karl Polanyi's critique. Cambridge: Harvard University Press.

Blyth, Mark. 2002. Great transformations: Economic ideas and institutional change in the twentieth century. Cambridge: Cambridge University Press.

Bockman, Johanna, et al. 2016. "Socialist accounting" by Karl Polanyi; with preface "Socialism and the embedded economy". Theory and Society 44:385-427. https://doi.org/10.1007/s11186-016-9276-9.

Brick, Howard. 2006. Transcending capitalism. Visions of a new society in modern American thought. Ithaca: Cornell University Press.

Brinkley, Alan. 2010. The publisher: Henry Luce and his American century. New York: Alfred A. Knopf.

Burnham, James. 1941. The managerial revolution: What is happening in the world? New York: The John Day Company.

Chase, Stuart. 1945. Democracy under pressure: Special interests vs. the public welfare. New York: Twentieth Century Fund.

Coser, Lewis. 1984. Refugee scholars in America. New Haven: Yale University Press.

Dale, Gareth. 2010. Karl Polanyi: The limits of the market. Cambridge: Polity.

Dale, Gareth. 2016a. Karl Polanyi: A life on the left. New York: Columbia University Press.

Dale, Gareth. 2016b. Reconstructing Karl Polanyi: Excavation and critique. London: Pluto Press.

Eisenberg, Christiane. 2011. Embedding markets in temporal structures: A challenge to economic sociology and history. Historical Social Research 36:55-78. https://doi.org/10.12759/hsr.36.2011.3.55-78.

Fermi, Laura. 1971. Illustrious immigrants: The intellectual migration from Europe 1930-41. Chicago: University of Chicago Press.

Hayek, Friedrich. 1944. The road to serfdom. Chicago: University of Chicago Press.

Heimann, Eduard. 1929. Soziale Theorie des Kapitalismus. Theorie der Sozialpolitik. Tübingen: Mohr.

Heimann, Eduard. 1947. Freedom and order: Lessons from the war. New York: Scribner.

Hutchinson, George. 2018. Facing the abyss: American literature and culture in the 1940s. New York: Columbia University Press.

Immerwahr, Daniel. 2009. Polanyi in the United States: Peter Drucker, Karl Polanyi, and the midcentury critique of economic society. Journal of the History of Ideas 70:445-466.

Katznelson, Ira. 2003. Desolation and enlightenment: Political knowledge after total war, totalitarianism, and the holocaust. New York: Columbia University Press.

Katznelson, Ira. 2013. Fear itself: The new deal and the origins of our time. New York: W. W. Norton.

Koselleck, Reinhart. 2000. Erfahrungswandel und Methodenwechsel. Eine historisch-anthropologische Skizze. In Zeitschichten, ed. Reinhart Koselleck, 27-77. Frankfurt a. Main: Suhrkamp.

Kuttner, Robert. 2017. The man from red Vienna. https:/www.circolorossellimilano.org/MaterialePDF/ the_man_from_red_vienna.pdf. New York Review of Books. December 21, 2017:55ff.

Lederer, Emil. 1940. State of the masses: The threat of the classless society. New York: W. W. Norton.

Litvan, György. 1991. Democratic and socialist values in Karl Polanyi’s thought. In The legacy of Karl Polanyi: Market, state and society at the end of the twentieth century, ed. Marguerite Mendell, Daniel Salée, 251-271. New York: Palgrave MacMillan.

Lukács, Georg. 1971. History and class consciousness: Studies in Marxist dialectics. Cambridge: MIT Press. (1923).

Mann, Michael. 2012. Global empires and revolution, 1890-1945. The sources of social power, Vol. 3. Cambridge: Cambridge University Press.

Polanyi, Karl. 1941. Letter to Michael Polanyi, August, 22, 1941. Michael Polanyi Papers. Chicago: University of Chicago. Joseph Regenstein Library, Department of Special Collections. Box 17, Folder 9.

Polanyi, Karl. 1943a. Jean Jacques Rousseau: Or is a free society possible? Michael Polanyi Papers. Chicago: University of Chicago. Joseph Regenstein Library, Department of Special Collections. Box 17, Folder 10.

Polanyi, Karl. 1943b. Letter to Michael Polanyi, July, 8, 1943. Michael Polanyi Papers. Chicago: University of Chicago. Joseph Regenstein Library, Department of Special Collections. Box 17, Folder 10.

Polanyi, Karl. 1944. The great transformation. New York: Farrar and Rinehart.

Polanyi, Karl. 1945. Origins of our time: The great transformation. London: Victor Gollancz.

Polanyi, Karl. 1947. Our obsolete market mentality. Civilization must find a new thought pattern. Commentary 4:109-117.

Polanyi, Karoly. 1986. Karl Polanyi 1886-1964. Budapest: Fővárosi Szabó Ervin Könyvtár. 
Polanyi-Levitt, Kari, and Marguerite Mendell. 1987. Karl Polanyi: His life and times. Studies in Political Economy 22:7-39.

Polanyi-Levitt, Kari. 2007. The English experience in the life and work of Karl Polanyi. In Karl Polanyi: New perspectives on the place of the economy in society, ed. Mark Harvey, et al., XI-XVI. Manchester: Manchester University Press.

Rogan, Tim. 2017. The moral economists: R. H. Tawney, Karl Polanyi, E.P. Thompson, and the critique of capitalism. Princeton: Princeton University Press.

Rosenberg, Hans. 1934. Die Weltwirtschaftskrisis von 1857-1859. Stuttgart: Kohlhammer.

Rosenberg, Hans. 1943. Political and social consequences of the great depression of 1873-1896 in Central Europe. The Economic History Review 13:58-73.

Rosenberg, Hans. 1967. Große Depression und Bismarckzeit. Wirtschaftsablauf, Gesellschaft und Politik in Mitteleuropa. Berlin: De Gruyter.

Steinberg, Marc W. 2016. England's great transformation: Law, labor, and the industrial revolution. Chicago, London: University of Chicago Press.

Westbrook, Robert B. 1991. John Dewey and American democracy. Ithaca: Cornell University Press.

Willkie, Wendell L. 1943. One world. London: Cassell and Company.

Marcus Gräser is Head of Department and Professor of Modern and Contemporary History at JKU Linz. His main areas of interest are modern American, German and Habsburg/Austrian history in a comparative/ transnational/global history framework. He is presently preparing the volume on North America in the series "Neue Fischer Weltgeschichte". He has recently edited the volume "The Transnational Significance of the American Civil War" (Basingstoke 2016, together with Jörg Nagler and Don Doyle). 